\title{
The Codification of the Transport Legislation in Albania under EU Integration Process: Is It an Italian Model?
}

\author{
Leonard Kadrimi \\ PhD Candidate, \\ UET, Albania
}

\author{
Prof. Assoc. Dr. Arber Gjeta \\ Department of Law, \\ University of Elbasan, Albania
}

\begin{abstract}
In recent decades the process of EU integration has driven the Albanian legislation development. The adoption of legislation in line with the acquis was often made not through real legislative process but as a need of implementation of EU regulations and directives, with the assistance of EU experts. This process not only has offered the best models of legislation but, it has also taken into account the specifics of the Albanian legal system. Through this paper we aim to provide an overview of the implementation of acquis in the field of transport law, and also offer an insight on how Albania has regulated the sector based on international conventions, EU legislation and foreign models like the case of Italy. On one hand Albania has adopted Codes for the regulation of railway, air and maritime transport and on the other hand there are laws that regulate road transport. These Codes are to be considered as an exhaustive of their field of competence, following the patterns of Italian legislation, but yet there are evidences that these Codes are far away from being considered as autonomous within the legal system. However, there is still a lack of secondary legislation that finds its origin in these codes. For the purposes of this paper we will take in consideration the approval and the entry into force of the Maritime and Air Codes and their alignment with the EU legislation and international conventions.
\end{abstract}

Keywords: Transport, Codification, models of codification, EU legislation

\section{Introduction}

The process of codification is very difficult within a legal system due to menacing of renewing a certain piece of legislation in a whole sector, more in detail that of transport, with all the other secondary legislation produced and interpretations provided by the courts and from scholars. Also, these processes reshape legislations and bring uncertainty regarding the interpretation and implementation from the professionals and businesses. In the present case that we are trying to analyze, this process is certainly 


\section{Journal of International Cooperation and Development}

www.richtmann.org/journal

Vol 2, No 2, November 2019

driven due to the fact that the update of the legislation Albania in this scenario in is shaped according to an important model that is the EU legislation and the most relevant international conventions of the sector. Due to this fact, we can assume that this process has brought improvements in the Albanian legislations and we find that, in practice, it will bring certainty in the system and a better regulation. In order to do so, there is the need for the secondary legislation to be established as soon as possible by the government and it needs to be also in line with the provisions of the primary legislation, the Codes adopted so far.

\section{Methodology}

In this paper we aim to study the process of codification in Albania by doing a descriptive analysis of the legislation approved so far, and also combining a comparative analysis with other models in other legislations, such as the case of in Italy. We will also provide some important insights on the models of codification followed by the Albanian lawmakers. Methodologically we analyze the Codes adopted in Albania in comparison with the EU relevant legislation and, at the same time, conduct a historical analysis on the changes made so far with regards to the process of stabilization and association of Albania toward EU integration that derives from ASA Agreement of 2006.

Our study has some limitations, as we do not fully assess the impact of these pieces of legislation in practice and give findings from the court rulings so far.

We aim to find that, despite these Codes are a request of adoption of acquis communautaire, their adoption must be considered as a serious improvement of the Albanian legislation in the sector of transport.

\section{The Process of Codification in the Transport Law in Albania: The Reasons Behind the Process}

In the Albanian legislation, there can be noticed two breaking points within the legal system. The first one is the changes made after the fall of communist regime in the ' 90 . There was a first attempt, under the supervision of the CMI, to draft the first Albanian Maritime Code, which resulted to be unsuccessful. Whereas, with regards to the aviation law, it was adopted the first law regulating the sector, Law no. 7877 dated 30/11/1994 "On Albanian Civil Aviation". However, it wasn't opted for a codification in the aviation sector. Road transport was also regulated by state law with the Law no. 8308 dated 18/03/1998 "On road transport", amended several times and still in force. In the railway sector the lawmakers didn't intervene during the first years of the transition, by maintaining in force the Law no. 7224 dated 22/06/1988 "Railway Transport Code of the Socialist Republic of Albania" until the adoption of the law in force, which is Law no. 9317 dated 18/11/2004 "Railway Transport Code of the Republic of Albania". 


\section{Journal of International Cooperation and Development}

www.richtmann.org/journal

Vol 2, No 2, November 2019

The regulation offered by these laws was the first set of rules to regulate the field of transport, after the falling of the communist regime, according to the principles of the free market economy. Yet, the regulation offered was in line with the duty taken by Albania according to the international regime but, on the other hand, this regulation does not reflect the best models of legislation or the recent trends and changes in the EU transport legislation ${ }^{1}$.

The second relevant moment, that affected the process of codification, was entering in the Stabilization and Association Agreement with the EU, ratified with Law no. 9590 dated 27/07/2006 and its provisions on achieving the rule of law through the adoption of the acquis communautaire, as a main duty of the Albanian party in order to fulfill its duties prior to the affiliation with the EU. In this agreement, the Article 70 "recognizes the importance of the approximation of Albania's existing legislation to that of the Community and of its effective implementation. Albania shall endeavor to ensure that its existing laws and future legislation shall be gradually made compatible with the Community acquis. Albania shall ensure that existing and future legislation shall be properly implemented and enforced". Yet, there are other provisions of the agreement that Albania must meet in its path toward the EU integration ${ }^{2}$ and the provision on transport sector are deemed as crucial due to the nature of the sector as an international industry and as crucial for the establishment of a common market ${ }^{3}$.

We must mention here the fundamental importance of the principle of subsidiaries in the transport sector, although it is a principle which is difficult to measured and established. Through subsidiaries, the Community pursues its objectives by removing obstacles to the free provision of services and the implementation of free competition. In this way it affects the sphere of competence of the individual States (descending vertical subsidiary), in matters traditionally reserved for state competence such as

1 The EU is the most important economic partner of Albania and it is reflected even in the transport sector.

${ }^{2}$ See Title VIII of the Stabilization and Association Agreement signed on 12 June 2006, sotto la rubrica "Cooperation policies", in specific in its article 106 on transports that states that "Cooperation between the Parties shall focus on priority areas related to the Community acquis in the field of transport" that aims principally to "restructuring and modernizing the Albanian transport modes, improving the free movement of passengers and goods, enhancing the access to the transport market and facilities, including ports and airports, supporting the development of multimodal infrastructures in connection with the main trans-European networks, notably to reinforce regional links, achieving operating standards comparable to those in the Community, developing a transport system in Albania compatible and aligned with the Community system and improving the protection of environment in transport." in OJEU L 107/166 of 28 April 2009.

3 P.J. SLOT, Sectorial policies (Transport) in The law of the European Union and the European Communities, (eds.) A. MCDOnNELL, P.J.G. KAPTEYN, K. Mortelmans, C.W.A. Timmermans, Kluwer Law International, IV ed., 2008, p. 1172. The Author emphasises the nature of transport as a international sector. 


\section{Journal of International Cooperation and Development}

www.richtmann.org/journal

Vol 2, No 2, November 2019

ownership, security, public services that are particularly relevant in the port or airport sector "where the most marked reveals the conflict between public interest and liberalization".

Thus, the process of integration in the EU constitutes the main path for Albania and the adoption of the acquis is one of the most important tasks to perform. This is reflected in the sector of transport as well.

\section{The Albanian Legislative Acts Beside Transport Sector Codes}

The legislative framework that regulates transport in Albanian is now shaped according to the EU legislation and the adoption of each singular act shall be seen in correlation with the fulfillment of the tasks under SAA with the EU and the adoption of the acquis. In different transport modes the lawmaker has chosen to adopt Codes as Aviation, Railway or Maritime Code in order to regulate organically and with autonomy the sectors which these affect.

\subsection{The regulation in maritime sector}

The maritime legislation in Albania lays on Maritime Code ${ }^{5}$, adopted in 2004, and in several secondary acts and specific laws that regulates in detail several issues like security and maritime infrastructures. The Maritime Code, with its 403 articles is to be considered as complete and exhaustive in regulation of the maritime navigation. It was drawn based on best models and under the guidance of foreign experts.

Other acts that are important, besides the law that ratifies the international convention of the sector, are: Law no. 168 dated 30/10/2013 "On security in ships and ports", Law no. 10109 dated 02/04/2009, "On Maritime Administration of the Republic of Albania", Law no. 9130 dated 08/09/2003 "On Port Authority". The latest represents the most important innovation in the whole maritime sector.

The Law no. 9130 of 2003 disposes on Port Authorities and regulates their functioning. Approved one year before the entry into force of the Maritime Code we must assume that it was totally in line with the new coming code. Thus, regarding maritime transport the set of legislation is up to date despite many ports are not yet functioning as private ports but as state owned companies. Regarding special legislation there are several other pieces of special legislation that shall be harmonized with EU acquis as in example the competition issues or state aid legislation. Still the Maritime

\footnotetext{
4 A. XERRI, Il principio di sussidiarietà nel diritto dei trasporti in Trasporti: Diritto, Economia, Politica, n. 109, 2009, p. 43-44. Amplius on the subsidiariety principle regarding infrastructures see S.M. Carbone, F. MunarI, Principio di sussidiarietà e disciplina comunitaria di porti, aeroporti ed infrastrutture del trasporto in Diritto dell'Unione Europea, n. 3, 2002, p. 431 e ss.

${ }^{5}$ Law no. 9251 date 08.07.2004 "Maritime Code of the Republic of Albania", amended.
} 


\section{Journal of International Cooperation and Development}

www.richtmann.org/journal

Vol 2, No 2, November 2019

Code represents a comprehensive piece of legislation that regulates maritime affair in their totality.

\subsection{The process of codification regarding railway transport}

In the railway sector the process of codification had a different path due to the fact that the railway transport in Albania was underestimated and, after communism, was depredated into a residual way of transport. In the first period of codification, which corresponds with years 2002-2005 the Albanian legislator adopted a Code of Railway transport which repealed the old Law no. 7224 of 1988 "Railway transport code of the Socialist Republic of Albania"6. The Code of 2004 aims to set an up to date piece of legislation in order to renew the interest of investors within the railway sector and to revitalize the transport by $\operatorname{train}^{7}$ through the adoption of a first market opening and introduction of the notion of unbundling between infrastructure management and railway transport operators. Yet, the railway sector remained underestimated and railways were run directly through state companies.

In 2016, due to the aforementioned obligations within the process of integration in the EU and the will to enhance and improve railway sector in Albania, the legislator adopted a new Code of Railway Transport that repeals the Code of 2004.

The new Railway Code aims to partially harmonize the Albanian legislation to the EU acquis and in particular with Directive 2012/34/EU "On the creation of a singular railway European zone", Directive 2016/798 "On railway safety", Directive 2016/797/EU "On interoperability of the railway system within European Union", Directive 2007/59/EC, Regulation 2016/976/EU, Regulation 1370/2007/EU, Regulation $1371 / 2007 / E U$. Furthermore, in its aims fixed in article 2 the Code foresee to "a) establishment of a favorable and sustainable legal framework for the promotion and development of modern railway transport in the territory of the Republic of Albania; b) the development of efficient and competitive railway transport with other modes of transport, thereby creating the conditions for railway undertakings to have the status of independent operators and to adapt to market needs in accordance with good commercial practices; (c) the organization and functioning of the railway sector on the basis of the principles of separation of management and accounting separation between railway infrastructure and railway transport activities; ç) development and improvement of railway safety and market access for railway transport services through: i) the establishment of a Railway Regulatory Authority, a Railway Safety Authority, a Railway

\footnotetext{
"Law no. 9317 date 18.11.2004 "Rail transport Code of the Republic of Albania"

7 The scope of application set in article 1 provides that "The Railway Code of the Republic of Albania has as its object the determination and establishment of general rules and principles in the field of rail transport and of activities related to it"
} 


\section{Journal of International Cooperation and Development}

www.richtmann.org/journal

Vol 2, No 2, November 2019

Licensing Authority and a National Railway Accident and Incident Investigation Authority, clearly defining the way in which they interact; (ii) developing and implementing common security objectives and common security methods, with a view to harmonizing national rules". At the same time, this article fixes the principle that drive the EU railway sector as interoperability, unbundling or safety operations and aim to be a programmatic rule for the development of the railway sector in Albania when aims to "establish a favorable and sustainable legal framework for the promotion and development of modern railway transport" in the Albanian territory (art. 2 lett.a). Yet, in 2019 we do not have the secondary legislation or bylaws in order to implement the Railway transport Code. In the second term of 2019 the Government has launched for public consultation different legal drafts regarding the creation of the Authority of Regulation of Railway, for the creation of the Authority of Railway Security, etc. The draft-proposals are fully in line with the acquis communautaire and will give implementation to the provisions of the Code of Railway Transport of 2016.

\subsection{Regulation of the air transport sector}

The air sector in Albania is governed by the Air Code of the Republic of Albania, adopted with Law no. 10040 date 22.12.2008. The Air Code, differently than Maritime Code or the first Railway Code of 2004, was adopted after the signature of the Stabilization and Association Agreement. Thus, this piece of legislation offers a better harmonization with the EU legislation of the sector and, indeed, can be considered one of the best codes within Albanian legal system.

The other reason of the fortune of the Air Code is the intensity of commercial relations in this sector between EU and Albania. The experience and expertise offered in drafting the Air Code was greater and the duties of the Republic of Albania in front of the EU were mostly met.

Yet, actually, the Government is proposing a draft of a new Air Code that brings few substantive changes in regulating air transport sector according to the EU acquis. Thus, according to the Government in the relation that follows the proposed draft this new Code has adopted the mandatory regulation of Reg. 2018/1139 of the EU Parliament and Council and is in line with the acquis. Furthermore, the new Code has made progress in adopting the acts that are needed under the ECAA agreement ${ }^{8}$. The latest is

\footnotetext{
${ }^{8}$ As in the regard to the ECAA agreement the comprehensive assessment of the EU Commission in the 2012 Communication is the sequent: "Neighboring countries have done a great deal to align their regulatory framework with EU legislation in key areas such as aviation safety, security, air traffic management, environment, passenger rights, economic regulation and social aspects. This is in the interest of the consumers and aviation industry both of the EU and the neighboring countries. The EU gives significant assistance to neighboring countries in supporting them to align their legislation with EU rules. Both sides have agreed to grant additional traffic rights to apply
} 


\section{Journal of International Cooperation and Development}

www.richtmann.org/journal

Vol 2, No 2, November 2019

a multilateral agreement adopted in order to include Albania and the Western Balkans as a whole in a Single European Space there was initiated a project of a multilateral agreement between EU and Border States, mostly Western Balkans States ${ }^{9}$.

Furthermore, it was instituted the Civil Aviation Authority ${ }^{10}$, the National Agency for Accident Investigation ${ }^{11}$ and the reform of the National Agency of Air Navigation Traffic as a public company.

The process of codification in the air sector results completed and the new forthcoming Code, after passing all the legislative, it will enter into force with a high grade of harmonization with the acquis.

\subsection{Road transport}

Law 8308 dated 18.3.1998 "On Road Transport", as amended, regulates the activity of road transport in the Republic of Albania. This law has been amended several times shifting competencies between local and national governmet bodies, especially in the area of licensing for public transport ${ }^{12}$. Thus, the road transportation is regulated by state law and several times amended and there is not foreseen the adoption of a Code in this sector. The reasons are to be searched in the passivity of the legislator and its will to regulate the sector despite it was several times risen in doctrine the need for a new piece of legislation that had to consolidate the legislation of rod transport in Albania ${ }^{13}$.

Finally, especially for public transport, Law 10/2016 has introduced substantial changes. The accompanying reports in parliament state that the aim is to "improve the activity of inland passenger transport, align legislation with EU legislation and update legislation with new acts that have entered into force.

The main objective of the additions and changes proposed in Law No. 8308, dated 18.3.1998 "On Road Transport", as amended, is the reorganization of the market for the carriage of passengers by bus on regular routes within the country, as well as the

once the process of regulatory harmonization has been completed. In the case of the Western Balkans, the early implementation of EU aviation rules under the ECAA Agreement will also contribute to their efforts in the context of the EU accession process" COM(2012) 556 final, p. 17

${ }^{9}$ See on the topic A. GJETA, EU external aviation policy and the Western Balkans: what a future for the European Common Aviation Area? in Proceedings of Conference in Durres, 2014.

${ }^{10}$ L. n. $10233 / 2010$

${ }^{11}$ Decision of Counsel of Ministers n. 686/2010

${ }^{12}$ Amendments were made through Law no. 8908 of 2002; Law no. 9096 of 2003; Law no. 9373 of 2005; Law no. 9760 of 2007; Law no. 10137 of 2009; Law no. 10302 of 2010; Law no. 21 of 2013; Law no. 37 of 2014; Law no. 118 of 2012 and lately Law no. 10 of 2016, related the latest to the public transport and its licencing.

${ }^{13}$ A. GJETA, Transporti publik urban në Shqipëri: rruga drejt një rregullimi ligjor përfundimtar? in Proceedings of Conference Elbasan, 2017 


\section{Journal of International Cooperation and Development}

www.richtmann.org/journal

Vol 2, No 2, November 2019

approximation of the legislation of the European Union. country with that of the EU" ${ }^{14}$. The Government also states that it seeks to cope with the needs brought by law $115 / 2014$ "On the administrative-territorial division of local government units in the Republic of Albania".

\section{The Process of Codification in the Transport Sector}

The process of codification always involves difficulties starting from the assumption that it must culminate with an organic, complete and, in principle, autonomous corpus within the legal system ${ }^{15}$. Usually Codes are complete and exhaustively regulates a certain area of law.

Transport law, due to its nature as a legislative corpus destined to regulate a predominantly international economic activity such as navigation and transport, for the most part is regulated by legislation drawn up, precisely, at international level ${ }^{16}$. Thus, national legislation is mainly affected by international law. Yet, Albania has a singular regulation in transport area due to the fact that there are adopted three Codes and only road transport is regulated by law.

These legislative pieces are autonomous not only regarding common law but yet even other modes of transport making the process of interpretation very fragmented and missing the opportunity to a find a common lecture to the notion of transport.

Singular is the example of Italian Navigation Code that includes both parties, maritime and air navigation, under the same piece of legislation ${ }^{17}$. In the specific Italian

14 Relation on Draft-Proposal "PËR DISA NDRYSHIME DHE SHTESA NË LIGJIN NR.8308, DATË 18.3.1998, "PËR TRANSPORTET RRUGORE", TË NDRYSHUAR". Last seen in www.parliament.al (last access on 15/11/2019). Raporti i Komisionit të veprimtarive prodhuese. Raporti i Komisionit për Integrimin Europian

15 The autonomy enjoyed by the Italian navigation code in respect to the common law is well known. P. P. C. HAANAPPEL, The law and policy of air space and outer space: A comparative approach, The Hague, 2003, XIII

${ }^{16}$ It must be emphasized that the "international" nature of transport is a necessary condition for the uniform law conventions to be applied. In this regard, a division must be made between international instruments that only govern cases that have the character of "internationality" and the other instruments that also apply to situations that are internal to a given national order. See on the case of conventions as sources of law S. ZUNARELLI, M.M. COMENALE PINTO, Manuale di diritto della navigazione e dei trasporti, I, Padova, 2009, $50 \mathrm{ff}$.

17 In this regard, reference is made to the provisions of the Italian navigation code, the result of the work of the Neapolitan School and its founder, Antonio Scialoja, who advocated autonomy, specialty and the unity of navigation, maritime and air law. The latter was in truth an elite transport and accessory to maritime navigation, and for this reason there was only a single code. For a reconstruction of the doctrinal debate, in Italy and abroad, see: S. ZUNARELLI, M.M. COMENALE PINTO, Manuale di diritto della navigazione e dei trasporti, vol. I, Cedam, Padova, 2009, pp. 28-30; 


\section{Journal of International Cooperation and Development}

www.richtmann.org/journal

Vol 2, No 2, November 2019

case, the codification carried out in the past weighs heavily and decodification constantly was auspicated for a long time by navigation law scholars ${ }^{18}$, who have always hoped for a process of profound and organic reform ${ }^{19}$.

Lastly, it can be argued that legislative developments, both in aeronautical and maritime law, lead to the embrace of setting up a transport law that includes all forms of the implementation of the transport phenomenon, departing from the mere phenomenon of the nautical operations as a characterizing element of the discipline.

\section{Conclusions}

Normally the codification process culminates in a unitary system of rules that claim to be autonomous. Yet, as far as we saw in Albanian legal system we are still in a ongoing process in order to fully implement Codes regarding transport and adopting secondary legislation.

We opted in the field of transport for the creation of separate codes that have the character of a specialty rather than autonomy. The legislation cannot be reduced to uniform principles and concepts, albeit many principles, especially regarding navigation notion are similar.

The choice of Albanian legislator to adopt codes in the sector of transport mainly responds to the requests of the EU authorities in order to have a fixed legislation which needs a majority of 3/5 in Parliament in order to be amended. Furthermore, it will be auspicable to adopt a Code regarding Road transport due to the changes that were lately made to the sector and because substantial changes are made from its originating provisions.

On the other side there are different special sectors that are not regulated by codification like in example business law. We can find a reason for codification in transport sector in the commitments taken from Albanian in the process of Stabilization

M. Casanova, M. Brignardello, Diritto dei trasporti, Infrastrutture e accesso al mercato, Vol. I, Giuffrè, Milano, 2011, pp. 5-12.

${ }_{18}$ M. GRIGOLI, I/ diritto della navigazione fra codificazione e decodificazione, tomo I, ESI, Napoli, 1993, p. 6-7.

${ }_{19}$ M. GRIGOLI, II diritto della navigazione fra codificazione e decodificazione, Tomo II, ESI, Napoli, 1994, pp. 405-413. The author emphasis the "macroscopic delays and striking inadequacies in the structure of matter" and that only in recent times "has been made a conspicuous, but inorganic, emanation of legislative and regulatory provisions, in the laborious, and often clumsy, attempt to recover the many lost opportunities in starting an incisive reforming work of the by now anachronistic regulatory framework, crystallized in the ancient codified regime". The Author criticizes the position taken by Italy in the renewal process to which the uniform and supranational legislation has been subjected and puts the emphasis on the limits of the internal legislation to regulate the nautical phenomenon. 


\section{Journal of International Cooperation and Development}

www.richtmann.org/journal

Vol 2, No 2, November 2019

and Association in the EU, where the transport sector, due to its nature of internationality, has a significant relevance of being harmonized with priority, differently like other pieces of national legislation. The adoption of a Code offers more legal certainty and better regulation bringing out the regulation of the sector of transport out of the normal political debate and programs of various majorities within the Parliament.

\section{References}

A. Gjeta, EU external aviation policy and the Western Balkans: what a future for the European Common Aviation Area? in Proceedings of Conference in Durres, 2014

A. Gjeta, Transporti publik urban në Shqipëri: rruga drejt një rregullimi ligjor përfundimtar? in Proceedings of Conference Elbasan, 2017

A. Xerri, II principio di sussidiarietà nel diritto dei trasporti in Trasporti: Diritto, Economia, Politica, n. 109, 2009, p. 43-44

M. Casanova, M. Brignardello, Diritto dei trasporti, Infrastrutture e accesso al mercato, Vol. I, Giuffrè, Milano, 2011

M. Grigoli, Il diritto della navigazione fra codificazione e decodificazione, tomo I, ESI, Napoli, 1993

M. Grigoli, II diritto della navigazione fra codificazione e decodificazione, Tomo II, ESI, Napoli, 1994

P. P. C. Haanappel, The law and policy of air space and outer space: A comparative approach, The Hague, 2003, XIII

P.J. Slot, Sectorial policies (Transport) in The law of the European Union and the European Communities, (eds.) A. McDonnell, P.J.G. Kapteyn, K. Mortelmans, C.W.A. Timmermans, Kluwer Law International, IV ed., 2008

S. Zunarelli, M.M. Comenale Pinto, Manuale di diritto della navigazione e dei trasporti, I, Padova, 2009

S.M. Carbone, F. Munari, Principio di sussidiarietà e disciplina comunitaria di porti, aeroporti ed infrastrutture del trasporto in Diritto dell'Unione Europea, n. 3, 2002, p. 431 e ss. 